DOI: http://dx.doi.org/10.35137/iabk.v7i1.377

\title{
ANALISIS PIUTANG TIDAK TERTAGIH DAN UTANG TIDAK TERBAYAR TERHADAP ARUS KAS OPERASIONAL PADA CV CIPTA KARYA HARMONY
}

\author{
Cisa Dena Putri ${ }^{1}$ \\ ${ }^{1}$ Fakultas Ekonomi Universitas Krisnadwipayana \\ Kampus Unkris Jatiwaringin \\ Email : denacisa@gmail.com \\ Esti Damayanti ${ }^{2}$ \\ ${ }^{2}$ Fakultas Ekonomi Universitas Krisnadwipayana \\ Kampus Unkris Jatiwaringin \\ Email : estidamayanti1678@gmail.com
}

\begin{abstract}
Operational cash flow is a factor of the company's survival, so that positive cash flow is needed to support the company's activities. Factors that can affect operational cash flow are receipts from accounts receivable and debt payments. The purpose of this study is to analyze uncollectible receivables and unpaid debts to operational cash flow on CV Cipta Karya Harmony. This research method uses descriptive qualitative analysis which analyzes data by describing or describing data that has been collected and the results of this study indicate that uncollectible receivables and unpaid debt affect the company's operating cash flow.
\end{abstract}

Keywords : Non-collectible assets, Non-payment of Debt, Cash Flow

\section{PENDAHULUAN}

Untuk menjaga kesinambungan hidup perusahaan dalam jangka yang panjang, arus kas operasi adalah hal yang harus diperhatikan dan diperhitungkan oleh perusahaan, untuk itu perusahaan harus memperoleh arus kas yang positif dari kegiatan operasi. Karena jika arus kas perusahaan menghasilkan jumlah yang negatif, maka perusahaan tidak akan mampu meningkatkan kas dari sumber lain, sebab arus kas bersih dari aktivitas operasi merupakan ukuran utama likuiditas. Keberhasilan perusahaan dalam menjalankan bisnisnya hanya dapat diperoleh dengan pengelolaan keuangan perusahaan yang baik, khususnya pengelolaan arus kas sehingga modal yang dimiliki oleh perusahaan dapat berfungsi dengan baik.
Terdapat banyak faktor yang bisa memengaruhi arus kas operasional perusahaan, salah satunya adalah piutang tidak tertagih. Piutang tidak tertagih merupakan kondisi dimana debitur belum membayar utang kepada perusahaan. Piutang terjadi ketika perusahaan menjual produknya secara kredit. Proses penagihan piutang agar menjadi kas bagi perusahaan, dibutuhkan prosedur yang baik sehingga seluruh piutang perusahaan dapat ditagih. Apabila perusahaan tidak berhasil dalam melakukan penagihan piutang dan piutang memiliki jumlah yang besar, maka hal ini akan mengurangi bentuk piutang yang dapat ditagih dan perusahaan akan mengalami kerugian.

Selain piutang tidak tertagih, faktor lain yang dapat berpengaruh terhadap arus kas operasional adalah utang tidak terbayar. Suatu perusahaan ada kalanya 
akan melakukan pembelian secara kredit. Dengan demikian, perusahaan akan memiliki utang yang nantinya harus dibayar kepada supplier atau perusahaan lain sesuai dengan jatuh tempo utang. Pembelian kredit akan menyebabkan perusahaan tidak melakukan pengeluaran kas, dan berpengaruh bagi perputaran kas perusahaan yang akan memengaruhi efektivitas arus kas.

CV Cipta Karya Harmony adalah perusahaan jasa transportasi dengan nama brand Check Cargo yang memberikan pelayanan pengiriman barang ke seluruh Indonesia melalui darat, laut, maupun udara. Dalam menjalankan usahanya, perusahaan memiliki kebijakan memberikan penjualan secara kredit kepada pelanggan. Meningkatnya aktivitas penjualan kredit pada perusahaan mengakibatkan piutang perusahaan semakin meningkat. Dengan kondisi seperti ini,pengendalian piutang yang kurang baik akan mengakibatkan terhambatnya kas masuk. Pengendalian piutang yang kurang baik pada CV Cipta Karya Harmony ditunjukkan dengan besarnya piutang tidak tertagih sebagaimana disajikan dalam tabel berikut

Tabel 1. Piutang Tidak Tertagih Tahun

\begin{tabular}{|c|c|c|c|}
\hline \multicolumn{4}{|c|}{ 2016-2018 } \\
\hline Keterangan & $\begin{array}{l}31 \text { Desember } \\
2016\end{array}$ & $\begin{array}{l}31 \text { Desember } \\
2017\end{array}$ & $\begin{array}{l}31 \text { Desember } \\
2018\end{array}$ \\
\hline $\begin{array}{l}\text { Piutang belum } \\
\text { tertagih }\end{array}$ & 1.626 .535 .000 & 1.225 .425 .000 & 1.951 .842 .000 \\
\hline
\end{tabular}

Berdasarkan tabel diatas, pada tahun 2018 piutang tidak tertagih meningkat dari dua tahun sebelumnya. Terhambatnya kas masuk ke perusahaan akan mengganggu kondisi arus kas pada perusahaan dalam pengelolaan kas yang akan digunakan untuk pengeluaran, salah satunya untuk pembayaran utang.
Pengelolaan utang yang kurang baik pada CV Cipta Karya Harmony ditunjukkan dengan besarnya utang yang belum terbayar, sebagaimana disajikan dalam tabel berikut :

Tabel 2. Utang Tidak Terbayar Tahun

\begin{tabular}{lccc}
\multicolumn{4}{c}{$2016-2018$} \\
\hline Keterangan & $\begin{array}{c}31 \text { Desember } \\
2016\end{array}$ & $\begin{array}{c}31 \text { Desember } \\
2017\end{array}$ & $\begin{array}{c}31 \text { Desember } \\
2018\end{array}$ \\
\hline $\begin{array}{l}\text { Utang belum } \\
\text { terbayar }\end{array}$ & 2.462 .905 .000 & 1.244 .720 .000 & 2.571 .055 .000 \\
\hline Sumber: CV Cipta Karya Harmony, 2018 & &
\end{tabular}

Pengelolaan pembayaran utang perusahaan perlu dikontol dengan baik agar tidak terjadi penumpukan utang yang terlalu besar. Namun jika kas masuk dari penagihan piutang terhambat tentunya perusahaan akan mengalami kesulitan dalam mengalokasikan dana untuk pembayaran utang. Dengan kondisi seperti ini, CV Cipta Karya Harmony perlu meningkatkan kinerja perusahaannya dalam mengelola arus kas masuk dan keluar.Berdasarkan latar belakang diatas, penulis tertarik untuk menganalisis piutang tak tertagih dan utang tak terbayar yang terjadi di CV Cipta Karya Harmony dalam kaitannya dengan arus kas perusahaan.

\section{Piutang Tidak Tertagih}

Perusahaan akan mendapatkan lebih banyak keuntungan dari penjualan kredit karena penjualan kredit akan menarik lebih banyak pelanggan dan meningkatkan jumlah penjualan. Di sisi lain, penjualan kredit sering menimbulkan kerugian jika pelanggan tidak dapat memenuhi kewajiban dalam melunasi tagihannya. Ketika perusahaan menjual secara kredit, sebagian dari piutang biasanya akan sulit bahkan tidak dapat ditagih. Hal ini merupakan risiko yang harus diterima perusahaan yang memberikan kebijakan kredit. Kendati 
perusahaan sudah melakukan evaluasi terhadap pelanggan dan telah melakukan prosedur penangguhan yang efektif. Bahkan, masih ada beberapa pelanggan yang tidak bisa memenuhi kewajibannya. Biaya operasi dari piutang yang tidak tertagih disebut sebagai kerugian dari piutang.

Pelanggan yang tidak dapat membayarkan kewajibannya disebabkan oleh berbagai alasan, seperti pailit atau bangkrut, karakter dari pelanggan, force major dan lain sebagainya. Semakin banyak perusahaan memberikan penjualan kredit, semakin besar risiko piutang yang tidak dibayar. Horngren et al (2016:314) menyatakan apabila perusahaan tidak sanggup mengumpulkan piutang dari pelanggan dan menyebabkan biaya, disebut dengan beban kerugian piutang. Sedangkan menurut Reeve (2015: 417) yang diterjemahkan oleh Sam Setya menyatakan bahwa piutang yang tidak tertagih karena kegiatan penjualan kredit merupakan piutang yang tidak terbayar oleh konsumen dan menyebabkan kerugian bagi kreditor.

\section{Faktor-faktor Piutang Tidak Tertagih}

Menurut Rivai, dkk (2013:238-239) piutang tidak tertagih bisa terjadi oleh dua faktor yaitu :

Faktor Internal diantaranya : a. Kelalaian dari kreditor menaati kesepakatan pemberian piutang yang sudah ditegaskan;b. Pihak kreditor terlalu mudah memberikan utang yang disebabkan tidak ada patokan yang jelas tentang standar kekayaan; c.Konsentrasi piutang ke sekelompok pengguna jasa atau bisnis berisiko tinggi; d.Kurang mencukupi staf bagian penagihan piutang dan eksekutif; e. Kurangnya pelatihan dan pengawasan dari direksi kepada para staf bagian piutang dan eksekutif;f. Lemahnya perusahaan mendeteksi timbulnya piutang macet termasuk mendeteksi arah perkembangan arus kas pengguna jasa atau debitur lama.

Faktor Eksternal, yaitu :a. Memburuknya kondisi ekonomi perusahaan yang disebabkan oleh memburuknya kondisi ekonomi secara menyeluruh dan area bisnis di mana perusahaan beroperasi; b.Terjadi kesalahan proses dalam mengelola usaha atau bisnis perusahaan yang disebabkan kurangnya pengalaman dalam mengelola bisnis yang ditangani; c.Masalah keluarga seperti perceraian, kematian, penyakit yang berkepanjangan, pemborosan dana oleh satu atau lebih anggota keluarga debitur; d.Kegagalan debitur pada usaha debitur atau perusahaan debitur yang lain;e.Munculnya kejadian di luar kekuasaan debitur, seperti bencana alam, perang dan lain sebagainya;f.Tabiat debitur yang buruk (yang awalnya bermaksud tidak membayar kembali piutang).

\section{Kebijakan Utang}

Kebijakan dalam mengambil utang merupakan salah satu pembiayaan bagi perusahaan berasal dari pihak luar. Menurut Geedipalli et $a$ (2009) menyatakan bahwa, Pembiayaan utang merupakan pendanaan dalam tempo tertentu dengan kewajiban untuk melakukan pembayaran di waktu tertentu sesuai kesepakan yang telah di setujui dimasa yang akan datang. Ketidakberhasilan perusahaan membayar utangnya dapat membuat hilangnya kontrol perusahaan dan kebangkrutan. Utang adalah salah satu dari komponen rotasi modal bersama dengan penetapan kebijakan utang. Perusahaan dilihat mempunyai risiko jika memiliki jumlah struktur modal yang banyak dalam utang. 
Sedangkan jika perusahaan menggunakan sedikit atau tidak memiliki utang, perusahaan mungkin tidak dapat memperoleh tambahan modal dari luar untuk meningkatkan bisnis perusahaan. Pembiayaan utang dapat membuat risiko keuangan bagi perusahaan. Risiko ini merupakan tambahan yang ditanggung oleh pemegang saham biasa karena keputusan yang dilakukan untuk pembiayaan melalui utang. Perusahaan wajib melunasi utangnya. Ketika perusahaan lama dalam melakukan penyelesaian utangnya semakin dikit cadangan yang tersedia, semakin mudah perusahaan akan dapat memperoleh utang kembali. Terlepas dari situasi keuangan perusahaan, utang harus dibayar kembali pada titik waktu tertentu. Selain itu, bunga utang juga harus dibayar secara teratur oleh perusahaan untuk menjaga komitmen perusahaan.

Ketika perusahaan tidak mampu melakukan pembayaran utang pokok dan bunga pinjaman biasanya akan ada proses hukum di mana para investor tidak dapat memegang pengendalian keseluruhan atau sebagian perusahaan. Jika utang perusahaan semakin tingi, maka biaya tetap serta kewajiban yang harus dibayar juga semakin tinggi. Hal ini mungkin akan di dapat perusahaan ketika tidak dapat membayarkan pinjaman beserta dengan bunganya dan perusahaan mungkin akan kehilangan para kreditor.

Perusahaan yang memiliki utangnya terlampau tinggi, kemungkinan perusahaan akan mengalami kesulitan dalam keuangan. Di mana kondisi perusahaan berada dalam kesulitan keuangan dan terancam bangkrut, hal ini akan mengakibatkan biaya kebangkrutan. Jika perusahaan mengalami kebangkrutan perusahaan memiliki beban hukum dan akan mengalami kesulitan untuk mempertahankan pegawai perusahaan, pelanggan, serta para pemasok. Aset lain yang dimiliki perusahaan juga akan dilikuidasi dengan nilai yang lebih rendah dari pada nilai wajarnya apabila perusahaan melakukan kegiatan bisnisnya secara terus-menerus. Permasalahan yang berhubungan dengan bangkrutnya perusahaan kemungkinan akan semakin tinggi seiring semakin meningkatnya utang di dalam modal yang dimiliki oleh perusahaan. Biaya dari kebangkrutan mencegah perusahaan untuk tidak menggunakan pendanaan utangnya secara berlebihan.

\section{Arus Kas}

Laporan arus kas merupakan laporan yang menginformasikan ikhtisar secara terperinci dari semua arus kas masuk dan arus kas keluar serta sumber dan penggunaan uang tunai selama periode waktu tertentu. Informasi yang terkandung dalam laporan arus kas perusahaan memberikan dasar yang berguna untuk menilai kemampuan entitas untuk menghasilkan uang tunai dan setara kas untuk pihak internal dan eksternal. Tujuan paling utama dari laporan arus kas yaitu untuk memberikan informasi tentang pendapatan dan pengeluaran perusahaan selama periode waktu tertentu.

\section{METODE PENELITIAN}

Objek yang diteliti dalam penelitian ini adalah (1) Piutang tidak tertagih (2) Utang tidak terbayar (3) Arus kas operasional. Fokus penelitian ini adalah menggambarkan bagaimana analisis piutang tidak tertagih dan utang tidak terbayar terhadap arus kas operasional pada CV Cipta Karya Harmony dengan cara mempelajari dan menganalisis bagian terkait yang meliputi dokumen dan 
catatan yang digunakan, prosedur yang dilakukan beserta fungsi-fungsi yang terkait, serta pelaporannya.

Data yang digunakan dalam penelitian ini akan di analisis menggunakan analisis deskriptif. Metode ini bertujuan untuk menjelaskan hasil penelitian serta menggambarkan secara sistematis mengenai objek penelitian yang berhubungan dengan permasalahan yang diteliti. Metode ini diwujudkan dengan cara membuat analisis dan kesimpulan berdasarkan perbandingan antara data yang diperoleh dengan dasar teori relevan..

Langkah-langkah dari penelitian kualitatif deskriptif yang peneliti gunakan yaitu :

1. Pengumpulan Data

Kegiatan pengumpulan data pada penelitian ini dengan menggunakan observasi dan data sekunder.

2. Reduksi Data

Data yang sudah diperoleh ditulis dalam bentuk laporan yang terperinci. Laporan tersebut dirangkum dan difokuskan pada halhal yang penting berdasarkan satuan konsep atau tema untuk memberikan gambaran yang lebih tajam tentang hasil pengamatan.

3. Display Data

Data yang diperoleh dikategorikan menurut pokok permasalahan dan dibuat dalam bentuk matriks. Hal ini dilakukan untuk memudahkan peneliti melihat hubungan satu data dengan data lainnya.

4. Analisis Data

Peneliti menganalisis data yang telah direduksi dan telah dibuat dalam bentuk matriks. Analisis ini diberikan penjelasan dalam bentuk kata-kata untuk mendeskripsikan fakta yang ada.

5. Mengambil Kesimpulan
Langkah selanjutnya yang dilakukan oleh peneliti adalah menyimpulkan hasil analisis dan melakukan verifikasi atas data-data yang sudah diproses sesuai dengan pola pemecahan permasalahan yang dilakukan.

\section{HASIL DAN PEMBAHASAN}

Berdasarkan penelitian yang telah dilakukan oleh peneliti pada CV Cipta Karya Harmony mengenai analisis piutang tidak tertagih terhadap arus kas operasional, peneliti menemukan bahwa penagihan piutang usaha yang belum sesuai dengan standar operasional prosedur perusahaan. Kondisi ini berdampak pada terhambatnya arus kas masuk dari penerimaan piutang. Hal ini dibenarkan oleh perusahaan sebagai salah satu penyebab banyaknya penunggakan piutang. Jika tidak ada penambahan arus kas masuk maka modal yang seharusnya bertambah akan digunakan untuk biaya operasional dan laba yang diperoleh oleh perusahaan akan semakin kecil.

Berikut ini adalah persentase mengenai piutang tidak tertagih pada tahun 20162018 sebagai berikut :

Tabel 3. Persentase Piutang Tidak Tertagih Tahun 2016

\begin{tabular}{cccccc}
\hline & \multicolumn{5}{c}{ Umur Piutang } \\
\cline { 2 - 6 } Tahun Total Piutang & Belum jatuh & $01-30$ & $31-90$ & $91-180$ & $<180$ \\
& tempo & Hari & Hari & Hari & Hari \\
\hline
\end{tabular}

$\begin{array}{llllll}2016 & 1.626 .235 .000 & 329.087 .000 & 864.325 .000 & 406.081 .000 & 26.742 .000\end{array}$

\begin{tabular}{llll}
\hline $\begin{array}{l}\text { Persentase umur } \\
\text { piutang }\end{array} 20,25 \%$ & $53,14 \%$ & $24,97 \%$ & $1,64 \%$
\end{tabular}

Sumber : Diolah penulis, 2019 
Tabel 4. Persentase Piutang Tidak Tertagih Tahun 2017

\begin{tabular}{|c|c|c|c|c|c|c|}
\hline \multirow[b]{2}{*}{ Tahun } & \multirow[b]{2}{*}{ Total Piutang } & \multicolumn{5}{|c|}{ Umur Piutang } \\
\hline & & $\begin{array}{c}\text { Belum } \\
\text { Jatuh tempo }\end{array}$ & $\begin{array}{c}1-30 \\
\text { Hari }\end{array}$ & $\begin{array}{c}31-90 \\
\text { hari }\end{array}$ & $\begin{array}{c}91-180 \\
\text { hari }\end{array}$ & $\begin{array}{l}<180 \\
\text { hari }\end{array}$ \\
\hline 2017 & 1.225 .425 .000 & 301.043 .000 & 788.288 .000 & 136.094 .000 & - & - \\
\hline \multicolumn{2}{|c|}{ ?ersentase umur piutang } & $24,57 \%$ & $64,33 \%$ & $11,11 \%$ & - & . \\
\hline
\end{tabular}

Tabel 5. Persentase Piutang Tidak Tertagih Tahun 2018

\begin{tabular}{|c|c|c|c|c|c|c|}
\hline \multirow[b]{2}{*}{ Tahun } & \multirow[b]{2}{*}{ Total Piutang } & \multicolumn{5}{|c|}{ Umur Piutang } \\
\hline & & $\begin{array}{c}\text { Belum } \\
\text { Jatuh tempo }\end{array}$ & $\begin{array}{r}1-30 \\
\text { hari } \\
\end{array}$ & $\begin{array}{c}31-90 \\
\text { hari }\end{array}$ & $\begin{array}{c}91-180 \\
\text { hari }\end{array}$ & $\begin{array}{l}<180 \\
\text { hari }\end{array}$ \\
\hline 2018 & 1.951 .842 .000 & 631.522 .500 & 1.161 .293 .500 & 159.026 .000 & . & - \\
\hline Persent & se umur piutang & $32,36 \%$ & $59,50 \%$ & $8,15 \%$ & - & - \\
\hline
\end{tabular}

Dari tabel diatas menunjukkan bahwa piutang tidak tertagih mengalami perubahan dari tahun ke tahun. Tanpa memperhitungkan piutang yang belum jatuh tempo, pada tahun 2016 perusahaan mengalami piutang yang telah jatuh tempo dan belum tertagih sebesar 79,75\% atau sebesar Rp. 1.297.148.000, dengan persentase terbanyak pada umur piutang 1-30 hari sebesar 53,14\%. Pada tahun 2017 terjadi penurunan jumlah piutang yang sudah jatuh tempo dan belum tertagih sebesar $75,44 \%$ atau turun sebesar 4,32\%, dengan persentase terbanyak pada umur piutang 1-30 hari sebanyak $64,33 \%$. Sedangkan pada tahun 2018 piutang yang telah jatuh tempo mencapai persentase titik terendah dari dua tahun sebelumnya yaitu sebesar $67,65 \%$ atau turun sebesar $7,79 \%$ dari periode sebelumnya, jumlah piutang yang sudah jatuh tempo dan belum tertagih pada tahun 2018 yaitu sebesar Rp. 1.320.319.500 dengan persentase terbanyak pada umur piutang 1-30 hari sebanyak $59,50 \%$ atau sebesar $\mathrm{Rp}$. 1.161.293.500
Tabel 6.Persentase Kondisi Arus Kas Perusahaan Dari Hasil Penjualan

\begin{tabular}{cccc}
\hline Tahun & Hasil penjualan & $\begin{array}{c}\text { Arus kas masuk } \\
\text { dari penjualan }\end{array}$ & $\begin{array}{c}\text { Persentase } \\
(\%)\end{array}$ \\
\hline 2016 & 9.126 .790 .000 & 7.500 .255 .000 & 82,18 \\
\hline 2017 & 6.978 .680 .000 & 5.753 .255 .000 & 82,44 \\
\hline 2018 & 8.214 .111 .000 & 6.262 .269 .000 & 76,24 \\
\hline \multicolumn{2}{l}{ Sumber : Diolah penulis, 2019} &
\end{tabular}

Berdasarkan tabel diatas arus kas masuk dari hasil penjualan pada tahun 2016 memiliki persentase sebesar 82,18\%. Pada tahun 2017 mengalami kenaikan yang tidak signifikan menjadi $82,44 \%$. Persentase terendah terjadi pada tahun 2018 sebesar 76,24\%, menurun sebanyak $6,2 \%$ dari periode sebelumnya. Rata-rata arus kas masuk dari hasil penjualan pada tahun 2016-2018 adalah sebesar $80,29 \%$.

\section{Analisis Utang Tidak Terbayar}

Berdasarkan hasil penelitian yang dilakukan oleh peneliti pada CV Cipta Karya Harmony mengenai analisis utang tidak terbayar terhadap arus kas operasional ditemukan bahwa dalam melakukan pembayaran utang perusahaan kepada vendor belum sesuai dengan Standar Operasional Prosedur. Kondisi ini disebabkan arus kas operasional yang digunakan untuk pembayaran utang kepada vendor kurang memadai untuk melunasi utang perusahaan. Hal ini dibenarkan oleh perusahaan sebagai salah satu penyebab banyaknya penunggakan utang perusahaan. Jika tidak ada penambahan kas operasional yang masuk maka modal yang seharusnya bertambah akan digunakan untuk pembayaran utang perusahaan sehingga laba yang diperoleh semakin kecil.

Penunggakan utang yang terlalu banyak dapat mengganggu kinerja keuangan, begitupun terhadap aspek 
operasional. Perusahaan akan mengalami hambatan dalam melakukan aktivitas operasional. Untuk menghindari hal tersebut, perusahaan harus meningkatkan pemasukan dari kas operasional khususnya pemasukan penerimaan penagihan dari pelanggan. Berikut persentase mengenai utang tidak terbayar pada tahun 2016-2018:

Tabel 7. Persentase Utang Tidak Terbayar Tahun 2016

\begin{tabular}{|c|c|c|c|c|c|c|}
\hline \multirow[b]{2}{*}{ Tahun } & \multirow[b]{2}{*}{ Total Utang } & \multicolumn{5}{|c|}{ Umur Utang } \\
\hline & & $\begin{array}{c}\text { Belum } \\
\text { jatuh tempo }\end{array}$ & $\begin{array}{l}1-30 \\
\text { haru }\end{array}$ & $\begin{array}{c}31-90 \\
\text { hari }\end{array}$ & $\begin{array}{l}91-180 \\
\text { hari }\end{array}$ & $\begin{array}{c}< \\
180 \\
\text { hari }\end{array}$ \\
\hline 2016 & 2.462 .905 .000 & 701.770 .000 & 1.436 .957 .000 & 259.971 .000 & 64.207 .000 & - \\
\hline Persenta & se umur utang & $28,49 \%$ & $58,34 \%$ & $10,56 \%$ & $2,61 \%$ & - \\
\hline
\end{tabular}

Tabel 8. Persentase Utang Tidak Terbayar Tahun 2017

\begin{tabular}{|c|c|c|c|c|c|c|}
\hline \multirow[b]{2}{*}{ Tahun } & \multirow[b]{2}{*}{ Total Utang } & \multicolumn{5}{|c|}{ Umur Utang } \\
\hline & & $\begin{array}{c}\text { Belum } \\
\text { jatuh tempo }\end{array}$ & $\begin{array}{c}1-30 \\
\text { hari }\end{array}$ & $\begin{array}{c}31-90 \\
\text { hari }\end{array}$ & $\begin{array}{c}91-180 \\
\text { hari }\end{array}$ & $\begin{array}{l}<180 \\
\text { hari }\end{array}$ \\
\hline 2017 & 1.244 .720 .000 & 316.296 .000 & 875.769 .000 & 52.655 .000 & - & - \\
\hline Persent & ase umur utang & $25,41 \%$ & $70,36 \%$ & $4,23 \%$ & - & - \\
\hline
\end{tabular}

Tabel 9. Persentase Utang Tidak Terbayar Tahun 2018

\begin{tabular}{|c|c|c|c|c|c|c|}
\hline \multirow[b]{2}{*}{ Tahun } & \multirow[b]{2}{*}{ Total Utang } & \multicolumn{5}{|c|}{ Umur Utang } \\
\hline & & $\begin{array}{c}\text { Belum } \\
\text { jatuh tempo }\end{array}$ & $\begin{array}{c}1-30 \\
\text { hari }\end{array}$ & $\begin{array}{c}31-90 \\
\text { hari }\end{array}$ & $\begin{array}{c}91-180 \\
\text { hari }\end{array}$ & $\begin{array}{l}< \\
180 \\
\text { hari }\end{array}$ \\
\hline 2018 & 2.571 .055 .000 & 958.909 .000 & 1.391 .792 .000 & 220.354 .000 & - & - \\
\hline Persent: & ase umur utang & 37,30 & 54,13 & 8,57 & 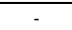 & - \\
\hline
\end{tabular}

Dari tabel diatas menunjukkan bahwa utang yang tidak terbayar mengalami perubahan dari tahun ke tahun. Tanpa memperhitungkan utang yang belum jatuh tempo, pada tahun 2016 perusahaan belum membayarkan utangnya yang telah jatuh tempo sebesar 71,51\% atau sebesar Rp. 1.761.135.000, dengan persentase penunggakan terbanyak pada umur utang 1-30 hari sebesar $58,34 \%$ atau sebesar
1.436.957.000. Pada tahun 2017 terjadi kenaikan persentase jumlah utang yang belum terbayar yang sudah jatuh tempo sebesar 74,59\% atau naik sebesar 3,08\% walaupun pada tahun 2017 total utang yang belum terbayar lebih rendah di bandingkan periode sebelumnya yaitu sebesar Rp. 928.424.000, dengan persentase terbanyak pada umur piutang 1-30 hari sebanyak 70,36\%. Hal ini menjadi catatan perusahaan karena dengan penurunan total utang yang lebih rendah dari tahun sebelumnya perusahaan justru memiliki tingkat persentase utang yang belum dibayarkan lebih banyak dari pada periode sebelumnya. Sedangkan pada tahun 2018 utang yang telah jatuh tempo dan belum terbayar mencapai persentase titik terendah dari 2 tahun sebelumnya yaitu sebesar $62,70 \%$ atau turun sebesar $11,89 \%$ dari periode sebelumnya, menjadi sebesar Rp. 1.612.146.000 dengan persentase terbanyak pada umur utang 1-30 hari sebesar 54,13\%.

\section{Tabel 10.Persentase Kondisi Arus Kas Perusahaan Dari Hasil Pembelian

\begin{tabular}{cccc}
\hline Tahun & Hasil pembelian & $\begin{array}{c}\text { Arus kas keluar } \\
\text { dari pembelian }\end{array}$ & $\begin{array}{c}\text { Persentase } \\
(\%)\end{array}$ \\
\hline & & & \\
2016 & 6.007 .310 .000 & 3.544 .405 .000 & 59,00 \\
\hline & & & \\
2017 & 3.872 .585 .000 & 2.627 .865 .000 & 67,86 \\
\hline & & \\
2018 & 5.406 .579 .000 & 2.835 .524 .000 & 52,45 \\
\hline Sumber: Diolah penulis, 2019
\end{tabular}

Berdasarkan tabel diatas arus kas keluar mengalami kenaikan dari tahun 2016 ke tahun 2017 sebanyak 8,86\%. Pada tahun 2018 arus kas keluar hanya sebesar $52,45 \%$ dari hasil pembelian, menurun sebesar $15,41 \%$ dari periode sebelumnya. Rata-rata arus kas keluar untuk pembayaran utang dari tahun 20162018 adalah sebesar 59,77\%. 


\section{Kondisi Arus Kas}

Perusahaan yang melakukan penjualan secara kredit dalam menjual produknya tentunya akan berpengaruh terhadap kondisi keuangan perusahaan dalam hal penerimaan kas. Terdapat faktor yang memengaruhi tidak tertagihnya piutang, baik dari faktor intern maupun faktor ekstern perusahaan. Hal ini harus diperhatikan oleh perusahaan agar piutang dapat ditagihkan tepat waktu dan menghindari terjadinya piutang tidak tertagih sehingga tidak mengganggu kinerja keuangan, khususnya dalam penerimaan arus kas operasional. Perlu strategi dan kebijakan dari manajemen perusahaan untuk menangani penagihan yang berisiko tidak tertagih atau macet agar kinerja keuangan perusahaan khususnya arus kas operasional memiliki kondisi dana yang stabil sehingga aktivitas perusahaan dapat berjalan dengan baik dan sesuai dengan rencana perusahaan.

Penerimaan arus kas yang masuk ke perusahaan yang diperoleh dari penerimaan piutang akan digunakan oleh perusahaan untuk membiayai aktivitas operasional termasuk dalam pembayaran utang kepada vendor perusahaan. Sebagian besar aktivitas operasional perusahaan di danai terlebih dahulu oleh pihak eksternal dengan jangka waktu pembayaran yang berbeda-beda. Pentingnya pembayaran utang yang tepat waktu akan berpengaruh terhadap hubungan kerja sama antar perusahaan dimana dana dari luar perusahaan sangat dibutuhkan oleh perusahaan yang belum memiliki dana cukup untuk membiayai aktivitas operasional perusahaannya.

Penunggakan piutang yang terlalu banyak dapat mengganggu kinerja keuangan, begitupun terhadap aspek operasional. Oleh sebab itu sangat diperlukan penagihan yang maksimal terhadap pelanggan dan diharapkan perusahaan dapat memberikan kebijakan yang lebih tegas terhadap pelanggan yang sering melakukan penunggakan, contohnya memberikan denda kepada pelanggan yang lalai dalam melakukan pembayaran. Perlunya peninjauan ulang terhadap pelanggan yang tidak sesuai dengan standar perusahaan juga harus dilakukan oleh perusahaan.

Berikut ini tabel yang menggambarkan kondisi piutang, utang dan kas operasional pada perusahaan CV Cipta Karya Harmony :

Tabel 11.Kondisi Piutang, Utang dan Kas Operasiona Tahun 2016-2018

\begin{tabular}{cccc}
\hline Tahun & Piutang & Utang & Kas Operasional \\
\hline 2016 & 1.297 .148 .000 & 1.761 .135 .000 & 2.534 .295 .000 \\
\hline 2017 & 924.382 .000 & 928.424 .000 & 2.057 .515 .000 \\
\hline 2018 & 1.320 .319 .500 & 1.612 .146 .000 & 2.280 .865 .500 \\
\hline Sumber: CV Cipta Karya Harmony, 2018 & &
\end{tabular}

Berdasarkan tabel diatas, melihat dari kondisi saldo kas operasional perusahaan pada setiap tahunnya. Peneliti menganalisis perlu prioritas dalam melakukan pembayaran utang kepada vendor yang telah jatuh tempo untuk menjaga ketersediaan saldo kas operasional perusahaan. Hal ini dilakukan agar pembiayaan-pembiayaan yang akan digunakan untuk aktivitas operasional lainnya dapat tetap dilakukan oleh perusahaan sehingga operasional perusahaan dapat tetap berlangsung. Disamping itu, perusahaan juga perlu melakukan penagihan piutang yang belum tertagih secara cepat terutama untuk pelanggan yang lalai dalam membayarkan piutangnya dengan umur piutang yang lebih dari 30 hari setelah jatuh tempo. Dalam hal ini apabila penunggakan piutang terjadi dikarenakan faktor dari pihak intern perusahaan, maka pihak manajemen perlu meninjau kembali 
kebijakan perusahaan yang berhubungan dengan piutang dan utang.

Dari penelitian ini, setelah peneliti menganalisis secara keseluruhan berdasarkan data pada tahun 2016-2018 mengenai analisis piutang tidak tertagih dan utang tidak terbayar terdapat pengaruh terhadap arus kas operasional. Terjadinya pengaruh ini dikarenakan penerimaan kas yang masuk dari penagihan piutang pelanggan digunakan kembali untuk pembiayaan kegiatan operasional salah satunya adalah pembayaran utang kepada vendor, dimana sebagian besar pembiayaan operasional perusahaan dibantu oleh dana dari luar perusahaan (utang) untuk melangsungkan kegiatan operasional perusahaan.

\section{Pembahasan}

Dari hasil penelitian piutang timbul akibat terjadinya transaksi penjualan secara kredit. Piutang yang telah jatuh tempo dan tidak terbayarkan maka akan menimbulkan piutang tidak tertagih pada CV Cipta Karya Harmony. Berdasarkan hasil penelitian piutang tidak tertagih pada periode 2016 sampai dengan 2018 memiliki rata-rata tidak tertagih yakni $19,71 \%$ sedangkan yang sudah tertagih yakni $80,29 \%$. Persentase umur piutang terbanyak terjadi pada 1-30 hari yakni $58,99 \%$. Dari piutang yang tidak tertagih pada perusahaan, dana yang seharusnya kembali berputar menjadi kas tetap tertanam dalam piutang.

Dari hasil penelitian juga ditemukan bahwa hal-hal yang menyebabkan piutang tidak tertagih adalah sebagai berikut :

1. Kelemahan perusahaan dalam memberikan kebijakan kredit pada pelanggan.

2. Kurangnya pengawasan dalam melakukan penagihan piutang.

3. Karakteristik dari pelanggan.
Dari penyebab yang menjadi faktor piutang tidak tertagih, usaha-usaha yang telah dilakukan oleh perusahaan untuk mencegah piutang tidak tertagih adalah sebagai berikut :

1. Mengonfirmasi kembali kepada pelanggan mengenai kebijakan kredit yang diberikan kepada pelanggan baik secara verbal maupun dalam bentuk surat.

2. Meningkatkan kepada pelanggan terkait piutang yang akan segera jatuh tempo.

3. Pada pelanggan tertentu meminta pelanggan untuk membayarkan uang muka sebelum pengiriman barang dilakukan.

Tentunya piutang tidak tertagih pada CV Cipta Karya Harmony memiliki dampak, yaitu semakin besar piutangpiutang tidak tertagih maka semakin besar kerugian perusahaan. Pada piutang yang tidak tertagih maka akan mengurangi piutang usaha yang akan terealisasi. Kaitan piutang tidak tertagih terhadap laporan keuangan, yaitu pada laporan laba rugi dimana semakin tinggi piutang yang disalurkan tidak tertagih semakin sedikit pula laba yang diperoleh. Dan arus kas masuk perusahaan juga akan terhambat.

Dari hasil penelitian utang tidak terbayar pada periode 2016 sampai dengan 2018 memiliki rata-rata utang tidak terbayar sebesar $59,77 \%$ sedangkan yang sudah dibayarkan oleh perusahaan yakni $40,23 \%$. Persentase umur utang terbanyak terjadi pada umur utang 1-30 hari $60,94 \%$. Hal ini disebabkan karena penerimaan penagihan piutang yang tidak lancar sehingga saldo kas di perusahaan tidak cukup untuk melakukan pembayaran seluruh utang usaha karena akan digunakan untuk pembiayaan operasional lainnya. Usaha-usaha yang dilakukan perusahaan untuk mencegah 
penumpukkan utang yang terlalu banyak adalah sebagai berikut :

1. Memaksimalkan penerimaan arus kas masuk sehingga ketersediaan dana pada perusahaan mencukupi untuk melakukan pembayaran utang.

2. Memprioritaskan pembayaran utang kepada utang yang telah jatuh tempo.

Utang digunakan untuk kegitan operasional atau investasi bagi perusahaan. Namunperusahaan harus memperhatikan pengunaan hutang secara efisien, maksudnya perusahaan harus dapat menyesuaikan jumlah utang dengan kegiatan operasionalnya agar dapat memperoleh laba yang diinginkan demi kelangsungan usahanya.

Utang yang terlalu besar menaikkan risiko pada perusahaan, karena biaya bunga merupakan biaya tetap yang harus dibayar. Ketika terjadi gangguan pada pendapatan, arus kas perusahaan akan kesulitan menutup biaya tetap, sehingga timbul risiko likuiditas di jangka pendek. Bila hal ini terjadi dalam waktu lama, akan timbul berbagai masalah yang berujung pada kebangkrutan.

\section{KESIMPULAN}

Berdasarkan perhitungan dan analisis yang telah peniliti lakukan dan paparkan pada bab-bab sebelumnya tentang Analisis Piutang Tidak Tertagih dan Utang Tidak Terbayar Terhadap Arus Kas Operasional pada CV Cipta Karya Harmony dengan menggunakan data tahunan dari laporan keuangan 20162018, diperoleh kesimpulan sebagai berikut :

1. Berdasarkan hasil penelitian piutang tidak tertagih, menunjukkan bahwa jumlah piutang yang tidak tertagih pada CV Cipta Karya Harmony tahun 2016 adalah 17,82\%, tahun
2017 adalah 17,56\% dan tahun 2018 adalah $23,76 \%$. Dari piutang yang tidak tertagih dapat dilihat bahwa jumlah piutang tidak tertagih perusahaan dari tahun ke tahun mengalami fluktuasi pada setiap tahunnya dan yang terbesar adalah pada tahun 2018. Semakin besar persentase jumlah piutang yang tidak tertagih akan semakin buruk bagi perusahaan, karena ini menandakan bahwa perusahaan tidak mampu mengatasi pengembalian piutang dengan baik.

2. Berdasarkan hasil penelitian utang tidak terbayar, menunjukkan bahwa jumlah utang tidak terbayar pada CV Cipta Karya Harmony tahun 2016 adalah $41 \%$, tahun 2017 adalah $32,14 \%$ dan tahun 2018 adalah 47,55\%. Dari utang yang tidak terbayar dapat dilihat bahwa jumlah utang tidak terbayar perusahaan dari tahun ke tahun mengalami fluktuasi pada setiap tahunnya dan yang terbesar adalah pada tahun 2018. Semakin besar persentase jumlah utang yang tidak terbayar akan semakin buruk bagi perusahaan, karena ini berarti menandakan bahwa perusahaan tidak mampu membayarkan kewajibannya.

3. Berdasarkan hasil penelitian arus kas operasional, menunjukkan bahwa arus kas yang masuk dari hasil penjualan tahun 2016 adalah $82,18 \%$, tahun 2017 adalah 82,44\% dan tahun 2018 adalah 76,24\%. Sedangkan arus kas operasional yang keluar dari hasil pembelian tahun 2016 adalah 59,00\%. Tahun 2017 adalah $67,86 \%$ dan tahun 2018 adalah 52.45\%.

4. Berdasarkan hasil penelitian dampak dari piutang tidak tertagih dapat mengganggu arus kas operasional 
perusahaan, seperti menimbulkan beban atau risiko terjadinya penumpukkan utang yang tidak terbayar tepat waktu, mengganggu jalannya kegiatan operasional perusahaan dan tujuan perusahaan dalam memperoleh keuntungan menjadi terhambat.

\section{DAFTAR PUSTAKA}

Aprilia, Widya. 2018. Analisis Piutang Tak Tertagih Berdasarkan Umur Piutang Pada Perumnas Regional I Medan. Skripsi. Medan : Universitas Medan

Baridwan, Zaki, 2014, Sistem Akuntansi Penyusunan Prosedur dan Metode, Edisi Kesepeluh, Yogyakarta : BPFE

Brigham, E.F., \& Houston, J.F, 2018, Dasar-dasar Manajemen Keuangan (Essentials of Financial Management), Buku 1, Edisi 14, (Alih Bahasa : Ali Akbar Yulianto), Jakarta : Salemba Empat

Bungin, Burhan, (2015), Metodologi Penelitian Kualitatif, Depok : Rajagrafindo Persada

Dewi, H. P, (2015), Pengaruh Perputaran Piutang dan Hutang Terhadap Arus Kas Operasional Studi Pada PT Exer Indonesia, Jurnal Akuntansi Bisnis, Vol 2, No. 2

Fauziah \& Puspitasi, (2014,) Analisis Hutang Lancar dan Penjualan Terhadap Profitabilitas, Jurnal Ilmiah Manajemen Kesatuan, Vol 2, No $1: 41-50$

Ferdinand, Augusty, (2014), Metode Penelitian Manajemen, Semarang : Badan Penerbit Universitas. Diponegoro

Fess, Reeve, Warren. 2015. Pengantar Akuntansi Edisi 25. Jakarta : Salemba Empat
Hartadi \& Alwin, (2016), Analisis Penerimaan Piutang Dagang dan Pembayaran Hutang Dagang Terhadap Arus Kas Pada CV. Gapici Junior Bag, Jurnal Ilmiah, Bekasi : STIE Mulia Pratama Bekasi

Horngren, Charles T, Walter T. Harrison \& Linda Smith Bamber, 2016, Akuntansi, Edisi keenam. Jakarta : PT Indeks Kelompok Gramedia

Husnan, Suad, dan Eny P, 2015, Dasardasar Manajemen Keuangan, Edisi Kelima, Yogyakarta : Penerbit UPP STIM YKPN

Kasmir, (2015), Analisis Laporan Keuangan, Jakarta: PT Rajagrafindo Persada

Keown, 2015, Manajemen Keuangan, Edisi Kesepuluh, Jakarta : PT Macanan Jaya Cemerlang

Kieso, Donald E. Jerry J.Weygand, Paul D. Kimmel, 2014, Accounting Principles Pengantar Akuntansi Edisi 7 Jilid 1, Jakarta : Salemba Empat.

Mahmoeddin, 2010, Melacak Kredit Bermasalah, Cetakan Pertama, Jakarta : Pustaka Sinar Harapan

Martani, Dwi dkk, 2016, Akuntansi Keuangan Menengah, Jakarta Selatan : Salemba Empat.

Mukhsinati, Sari. 2011. Analisis FaktorFaktor Penyebab Terjadiya Kredit Macet Pada Bank "X". Skripsi. Jember : Universitas Jember

Musthafa, 2017, Manajemen Keuangan, Yogyakarta : CV. Andi Offset

Reeve, James R., dkk, 2015. Pengantar Akuntansi Adaptasi Indonesia Edisi 21 Buku 1, Jakarta : Salemba Empat

Riyanto, P. 2014. Penggunaan Laba dan Komponen Arus Kas untuk Memprediksi Laba dan Arus Kas pada Perusahaan Manufaktur di Pasar Modal Indonesia Periode Tahun 1999-2002. Tesis, Program 
DOI: http://dx.doi.org/10.35137/iabk.v7i1.377

Studi Magister Akuntansi. Semarang : Universitas Diponegoro Semarang

Sari, A.La. 2015. Analisis Faktor-Faktor Penyebab Piutang Tak Tertagih Pada PT.Pelindo III (PERSERO) Cabang Tanjung Emas Semarang. Skripsi. Jurusan Akuntansi Fakultas Ekonomi.Semarang : Universitas Negeri Semarang

Soemarso, (2014), Akuntansi Suatu Pengantar, Jakarta : Salemba Empat

Wicaksana, I. 2014. Analisis

Pengendalian Piutang Terhadap

Efektivitas Arus Kas (Studi Kasus

Pada PT. Z). Skripsi. Departemen

Manajemen. Bogor : Institut

Pertanian Bogor

Wicaksono, Syerif . 2017. Analisis

Kinerja Keuangan Perusahaan

Daerah Air Minum (PDAM)

Kabupaten Pati. Tesis. Surakarta : Universitas Muhammadiyah

Surakarta

Wild, Subramanyam, \& Halsey, 2015, Analisis Laporan Keuangan. Edisi Kedelapan, Diterjemahkan oleh : Yanivi S. Bachtiar \& S. Nurwahyu Harahap. Jakarta : Salemba Empat Wiyono, Gendro \& Hadri Kusuma, 2017, Manajemen Keuangan Lanjutan Berbasis Corporate Value Creation, Edisi 1, Yogyakarta : UPP STIM YKPN 